Forthcoming Handbook of International Economics, Vol. II Edited by James Hartigan. London: Blackwell, 2004.

\title{
Modern Commercial Policy: Managed Trade or Retaliation?*
}

\author{
Thomas J. Prusa \\ Susan Skeath
}

\begin{abstract}
In this paper we study worldwide antidumping (AD) case filing patterns in order to determine the extent to which economic versus strategic incentives explain the behavior of countries employing $\mathrm{AD}$ actions. We compare four main hypotheses: big supplier, big change in imports, tit-for-tat and the club effect. We find strong support that AD actions are directed at big suppliers, but far weaker evidence that $\mathrm{AD}$ actions are filed against suppliers whose imports have surged. We also find very strong evidence that $\mathrm{AD}$ actions are used strategically to deter further use of $\mathrm{AD}$ and/or to punish trading partners who have used $\mathrm{AD}$. Our findings reject the notion that the rise in $\mathrm{AD}$ activity is solely explained by an increase in unfair trading.
\end{abstract}

\footnotetext{
* Prusa: Department of Economics, Rutgers University, New Brunswick, NJ, email: prusa@econ.rutgers.edu. Skeath: Department of Economics, Wellesley College, Wellesley, MA 02481, email: sskeath@wellesley.edu. We would like to thank Kyle Bagwell, Tom Pugel and Bernie Yeung for helpful conversations as well as seminar participants at the University of Otago, Australia National University, Hong Kong University of Science and Technology, and NYU for comments and suggestions on an earlier draft. Work on this project was started while Skeath was a Commerce Divisional Visiting Fellow at the University of Otago. Financial support from the Class of ' 32 Social Sciences Fund at Wellesley College is gratefully acknowledged. We would also like to thank WTO Rules Division and Jorge Miranda in particular and for making the WTO AD Measures Database available.
}

JEL Classification Number: F13 


\section{Introduction}

Modern commercial policy has been influenced significantly by the global movement toward freer trade and more open borders. Where tariffs and quotas once held sway over policy makers, antidumping and countervailing duty cases are now the path to WTO-legal protection. Antidumping in particular has become increasingly prevalent worldwide.

To say that antidumping is now the most popular form of international trade protection is an understatement. In terms of the quantity of trade litigation, antidumping has lapped the field - several times over. In 1999 for instance, WTO members reported 360 antidumping disputes. By contrast, they reported only 42 countervailing duty disputes. More astounding perhaps is the fact that countervailing duty law has long been the second most commonly used trade statute. Countervailing duty law takes the silver medal, but it is a far distant second.

The preeminence of antidumping is neither an entirely recent phenomenon nor simply a one-year anomaly. In the United States, for instance, over the past twenty-five years there have been more than twice as many antidumping disputes as countervailing duty allegations. In fact, there have been more disputes filed under the U.S. antidumping statute than under all other U.S. trade statutes put together. The same is true for the E.U. Antidumping (AD) is simply the 900pound gorilla of trade laws.

The rise in AD activity was not entirely unexpected. Ethier (1982, p. 488) warned that antidumping would be "the principal battleground for the 'new protectionism' as concerns trade in manufactures among the developed economies." But throughout most of the post-war era, it was easy for GATT negotiators to look the other way when it came to AD. After all, during that period, AD was really only a significant trade impediment for a handful of countries. Most countries either did not have an AD statute or chose not to use the law.

However, Ethier's words now ring true and low levels of AD use are no longer the norm. As a number of more recent authors have pointed out, the dramatic proliferation in the use of 
antidumping since 1980 is a particularly alarming development (Miranda, Torres and Ruiz, 1998; Prusa, 2001). More than three times the number of countries have been involved in AD disputes - both in terms of those filing cases and those being filed against - during the 1990s as compared with the 1980s.

One of the most disconcerting aspects of the growth, and certainly the most crucial for the issues examined in this paper, is the fact that the "traditional" users of antidumping (Australia, Canada, the E.U., New Zealand, and the U.S.) have been joined by an ever-growing group of "new" users, including South Africa, Brazil, and Mexico among others. Most of the new users did not even have their own antidumping statutes until the late-1980s.

As the number of users and cases filed annually grow, it is increasingly difficult to identify the motives of the users of $\mathrm{AD}$ and to argue that increased usage signals merely an increase in unfair trade. We are concerned, for example, that antidumping is increasingly being used as pure protectionism rather than as a valid trade remedy. It appears that AD's seductive lure of "WTO legitimate" protectionism is hard to resist and that an increasingly large number of countries are beginning to abuse the rules.

In Prusa and Skeath (2002), we provide some non-parametric evidence to suggest that the recent rise in $\mathrm{AD}$ activity cannot be explained solely by an increase in unfair trading practices. Here, we probe more deeply and examine whether there is any more significant empirical support for the proposition that AD filings are motivated by factors other than pure economics - by factors other than dollars and pesos so to speak. For the purposes of this paper, economic motivations include, say, filing AD complaints after a surge in imports, or perhaps even simpler, filing AD complaints against countries who hold the biggest import market share. In other words, we are willing to be agnostic as to whether such possibly benign patterns imply any unfair behavior. It is certainly possible that these patterns are consistent with unfairly low priced imports. 
By contrast, "non-economic" factors behind AD use include what we refer to as strategic or retaliatory motivations. For instance, when a country tends to file AD complaints against precisely those countries that have previous filed cases against it, we argue that its AD use is at least partially motivated by retaliation. Such behavior is completely inconsistent with the notion of $\mathrm{AD}$ as a way to combat unfair import practices. In fact, it suggests that countries view $\mathrm{AD}$ as a way to combat unfair governmental policies rather than a private firm's unfair practices.

In this paper we study worldwide $\mathrm{AD}$ filing patterns in order to determine whether we can identify the motivations for the increased use of $\mathrm{AD}$ disputes. In order to do so, we have compiled a database of all AD actions filed worldwide between 1980 and 1997 supplemented by trade statistics for each country filing cases.

Our analysis provides strong support for the view that strategic incentives influence AD filings. In particular, we find that, all else equal, $\mathrm{AD}$ users are far more likely to investigate suppliers who are also AD users. In other words, there appears to be a "club" effect, where countries that have used the law are also more likely to be subject to investigations. Further, we find some evidence that countries are also more likely to use AD specifically against those countries that investigated them in the past. This is the type of pattern one might expect from game players employing tit-for-tat strategies. All things considered, we believe our findings reject the notion that the rise in $\mathrm{AD}$ activity is solely explained by an increase in unfair trading.

The remainder of the paper proceeds as follows. In the next section we present a brief history of $\mathrm{AD}$ legislation along with a discussion of the growth in $\mathrm{AD}$ activity over the past two decades. In section 3 we review the theoretical models motivating our empirical approach. In section 4 we present parametric results. Concluding comments are made in section 5. 


\section{History and Background}

\section{$\underline{\text { Short History of Antidumping Legislation }}$}

Although opinions regarding AD vary, the facts regarding the laws and their use are clear. The focus of recent attention on $\mathrm{AD}$ has been the upsurge in use in the past two decades. However, antidumping laws have been in place for considerably longer and have an interesting history.

The first modern AD law (Act to Amend the Customs Tariff, 1897) was passed in Canada in 1904. Antidumping provisions were formally passed soon after in New Zealand (Agricultural Implement Manufacture, Importation and Sale Act, 1905) and Australia (Australian Industries Preservation Act, 1906). Both the United States and Britain passed their own statutes within the next fifteen years (the U.S. Revenue Act of 1916, and the Safeguarding of Industries Act of 1921, respectively) as did several European countries (e.g. France, in 1908) and most of the British Commonwealth (Finger, 1993, p. 16).

Some of the original antidumping laws were industry-specific, as in New Zealand, or based loosely on earlier competition law, as in the U.S. The 1916 American law used the 'intent to restrain competition' language of the Sherman Act of 1890. Such laws were relatively quickly replaced with statutes more similar to the Canadian one in which a more general "injury from imports" standard prevails (Finger, 1993, p. 21). The New Zealand Customs Amendment Act (1921) and the U.S. Antidumping Act (1921) both allowed broader administrative authority in the imposition of antidumping penalties with evidence of injury than did earlier acts.

Over the intervening years, these statutes have been variously amended, repealed, and replaced with more modern laws up to and through the period of negotiation of the GATT. In the United States, the most major changes occurred with the Tariff Act of 1930 and the Trade Agreements Acts of 1974 and 1979, although there were additional changes made in both 1984 (Trade and Tariff Act) and 1988 (Omnibus Trade Act). Many of the later changes made it easier 
for domestic firms both to prove the existence of dumping and to obtain relief under the law, including extensions of the definition of "less than fair value" to include both international price discrimination and sales below cost (Hufbauer and Elliott, 1994, p. 113). Elsewhere, in Europe, Canada and the British Commonwealth countries in particular, similar changes were being made to antidumping statutes throughout the century.

As individual nations tinkered with existing antidumping statutes or passed new ones during the latter half of the $20^{\text {th }}$ century, antidumping also became institutionalized in Article VI of the original formulation of the GATT in 1947. Article VI does not, however, specify how signatory countries should identify dumping behavior nor how they should make injury determinations. As a result, GATT member countries negotiated an additional agreement aimed at providing pertinent information on the implementation of Article VI. This "Agreement on the Implementation of Article VI" (more commonly called the Antidumping Agreement or the Antidumping Code), most recently revised during the 1994 Uruguay Round, regulates the use and application of Article VI by member countries. In particular, it details procedures for much of the antidumping process, including the determination of injury, collection of evidence, and imposition of duties.

The original version of the Code, negotiated during the Kennedy Round (1967), was of limited significance due in part to the fact that the U.S. did not sign that document. The Tokyo Round (1979) then produced some amendments to the Code that helped to transform what had been a little-used trade statute into the workhorse of international trade protection that is modern antidumping law. First, the definition of "less than fair value" sales was broadened to incorporate both price discrimination and below-cost sales, as had been done in the U.S. some years earlier. In addition, the Tokyo Round Agreement removed the provision that dumped imports be demonstrated as the "principal cause of material injury" before duties could be imposed. 
The Tokyo Round "improvements" in the AD Code were significant in opening the door to AD case filings. They also provided an important and useful general framework for investigations. Even the Tokyo Round agreement, however, bound only the 27 GATT member countries. It was not until the Uruguay Round (1994) that the AD Agreement came into force for a broader set of countries worldwide.

\section{$\underline{\text { Trends in Antidumping Filing Behavior }}$}

Despite the amount of legislative time and paperwork devoted to AD in the U.S., Europe, and the British Commonwealth over the first six decades of the twentieth-century, and by GATT signatories after 1947, AD disputes were not very common until the 1970s. Hufbauer (1999) notes that the U.S. filed a total of only 246 cases between 1934 and 1974, an average of only six per year. Worldwide, fewer than a dozen cases were filed by GATT member countries each year between 1948 and the early 1960s (Finger and Fung, 1994).

This relatively low level of activity began to change in the 1970 s, due in part to the amendments made to the GATT antidumping code in 1979 and to country-specific changes in antidumping legislation. In the U.S., for example, an average of 35 cases were filed each year in the second half of the 1970s (Finger and Fung, 1994, p. 199). Looking more broadly at the antidumping case filing history, we see that $\mathrm{AD}$ actions went on to become even more common during the 1980s; an average of 139 cases were filed each year from 1980 through 1989.

Despite the increase in its use in the two decades between 1970 and 1990, many did not view $\mathrm{AD}$ as a trading-system problem because it was an instrument still actually wielded by only a handful of countries. Prior to the late-1980s, essentially all AD actions were initiated by the five "traditional" users: the U.S., Canada, the European Union, Australia, and New Zealand. Specifically, traditional users were responsible for a total of $99.4 \%$ of all of the AD cases filed 
between 1980 and 1985 as well as for more than $95 \%$ of the cases filed during the entire decade of the 1980s.

By the late-1980s, however, the traditional users found they were no longer the only users of AD. In Figure 1 we detail the number of cases filed annually from 1980 through 1998, and we distinguish cases filed by traditional and new users. Looking at the figure, we see that by the late 1980s the traditional users began to be joined by a group of "new" users. These new users were responsible for no more than $5 \%$ of case filings in any year through 1986 , but filed $20 \%$ of all AD cases in 1987 and no less that $11 \%$ in any year thereafter.

Table 1 (see next page) provides some additional information on antidumping activity in the past two decades. In that table, we see that only nine GATT countries filed AD cases during the 1980 s while 39 did so during the 1990s. In addition, we can see that the group of new users first included countries such as Mexico and South Korea, and has since grown to include South Africa, Argentina, Indonesia, and Poland, among others. In fact, over the last ten years the set of new user countries has steadily grown to encompass nearly 30 countries, a third of whom have begun to use antidumping only in the second half of the 1990s.

Together, Figure 1 and Table 1 show that these new users are now eclipsing the traditional users in terms of the number of cases filed annually. In every year since 1993, new users filed more AD actions than traditional users. In 1996, for instance, new users accounted for nearly $70 \%$ of all AD cases. Overall, during the entire 1990 s new users accounted for more than $40 \%$ of the total number of cases filed.

To a large extent, the data suggest that the table has turned for the traditional users. The United States, the world's most prolific user of AD law, is now the second most investigated country, trailing only PR-China. Countries such as Mexico, Argentina, South Africa, Brazil, and India are now among the heaviest users of AD. 
Table 1 also shows that virtually none of the new users were strangers to antidumping actions before filing their own cases. Only two of the 27 countries that began using AD consistently after 1985 had never had AD cases filed against any domestic interests. Well over half of the countries had been named in at least $13 \mathrm{AD}$ cases before adopting their own statutes. Such striking trends certainly raise the specter that countries are using AD law for reasons other than punishing unfair trade.

\section{Schools of Thought Regarding Antidumping}

Broadly speaking, positions toward $\mathrm{AD}$ fall into three main camps. In the first camp are those who believe that $\mathrm{AD}$ simply protects against unfair trade and hence that the increase in $\mathrm{AD}$ actions reflects an increase in unfair trade. For example, McDonald (1998) and Mastel (1998) claim that the increased use of $\mathrm{AD}$ actions is largely due to liberalization and not an indication that AD is "out of control." Their argument is that as traditional trade barriers are lowered previously benign or irrelevant unfair pricing behavior becomes injurious and must be disciplined.

In the second camp are those who argue that $\mathrm{AD}$ facilitates trade liberalization by allowing countries to raise tariffs for those industries that are more significantly injured by imports than trade negotiators anticipated (Corden, 1974; Bagwell and Staiger, 1990). From this perspective, without the ability to resort to "special protection" countries could never have negotiated the wide-ranging reductions in tariff rates such as those achieved during the Tokyo and Uruguay Rounds of GATT. In other words, AD acts as a de facto safeguard mechanism. ${ }^{1}$

\footnotetext{
${ }^{1}$ Given that the injury standard under AD is much lower than under safeguard protection and that most countries do not have a national interest clause in their AD statute, the fact that $\mathrm{AD}$ acts as de facto safeguard protection raises concerns. Nevertheless, this observation is consistent
} 
Given the greater degree of economic interdependence and the increased volatility of exchange rates and trade volumes now observed worldwide, the increase in AD activity may simply reflect the greater need for ex post flexibility with respect to tariffs (Fischer and Prusa, 2003).

Finally, in the third camp are those who believe that AD is essentially a strategic or protectionist policy. For instance, it has been shown that AD promotes collusion by serving as a punishment device (Staiger and Wolak, 1991) and by coordinating pricing and quantity decisions (Prusa, 1992). There is also ample evidence that AD protection is most often granted to politically powerful industries (Finger, Hall and Nelson, 1982; Hansen and Prusa, 1995, 1996).

Whether the growth of $\mathrm{AD}$ activity raises or lowers welfare depends on what perspective is most accurate. From the perspective of the first two camps AD measures raise welfare; therefore, the growth of $\mathrm{AD}$ activity reflects how vital it is to the liberal trading system. On the other hand, from the perspective of the third camp AD is a loophole in the GATT/WTO rules; consequently, the growth of $\mathrm{AD}$ activity is a threat to free trade.

In the following section, we present a more comprehensive review of the various theories used to explain antidumping behavior. We then proceed, in Section IV, to test the hypotheses generated by these theories.

\section{Theory}

In its purest form, an $\mathrm{AD}$ action should occur only after an incident of dumping. There are problems with this conclusion, however, due in large part to the manner in which AD statutes are written. Countries generally have significant discretion in the use of AD law, and

with the view that $\mathrm{AD}$ facilitates trade liberalization. A subtler question is whether the abuse of $\mathrm{AD}$ is necessary for trade liberalization. 
implementation by the authorities is often poor. Thus, countries and individual industries within countries have learned that they can use the laws to their advantage in a variety of ways. As discussed above, we can classify explanations for $\mathrm{AD}$ actions into three broad schools of thought: (i) $\mathrm{AD}$ as a response to unfair trade, (ii) $\mathrm{AD}$ as special or safeguard protection, and (iii) $\mathrm{AD}$ as a strategic weapon, to punish those who have used it or to deter others from abusing it. These three "camps" serve to motivate the hypotheses to be tested.

\section{$\underline{\text { Unfair Trade }}$}

AD actions may be filed in response to unfair trade practices by importers. The standard theoretical explanation for AD is based on the existence of dumped imports, goods that are sold either at a price below that set in the importer's domestic market or at a price below the importer's cost of production, implying that goods are not sold at "fair value."

Brander and Krugman (1983) provide a formal theoretical treatment of dumping as international price discrimination. ${ }^{2}$ Their model shows that oligopolistic firms in segmented markets have profit-maximizing incentives to sell into each other's markets. Further, equilibrium export prices for each firm can fall below their domestic prices making their foreign sales qualify as dumped.

The first formal model of dumping as pricing below production cost appears in Ethier (1982). His model shows that factor market considerations in unfavorable periods can lead to below-cost export pricing in the international equilibrium. In both this case and that analyzed by Brander and Krugman (1983), domestic producers may experience losses due to the existence of dumped imports. Arguably, these are the losses that are the concern of international AD statutes. The GATT code provides for the imposition of AD duties in cases in which dumped imports are found to have caused such material injury to domestic firms.

2 This definition of dumping is that traditionally found in the literature. It can be traced at least to Viner who argued "for confining the term dumping to price-discrimination between national markets." (1923, p. 3) 
Given the level of detail at which we were able to construct our data set, we are constrained to use country-level data. Therefore, we cannot determine whether there have been actual instances of dumping or unfair trade practices. Instead, we will use indirect measures of unfair practices. For example, one could expect that exporting at unfairly low prices would result in large import volumes and/or large increases in imports and thus that AD cases would be directed at countries with such trends. ${ }^{3}$

\section{Special Protection}

It has long been argued that overall trade liberalization can only be achieved if countries have the ability to suspend their obligations for those industries that are more significantly injured by imports than trade negotiators anticipated. This view was formalized by Bagwell and Staiger (1990), who developed a game-theoretic model in which "special protection" arises as a shortterm cooperative remedy for changes in underlying trade flows.

Their basic structure is that of a repeated prisoners' dilemma game in which cooperative behavior is defined as imposing low tariff rates, while high tariff rates represent defection. In a repeated game, players could solve the dilemma by using contingent strategies, like tit-for-tat, that incorporate punishment schemes to handle instances of defection from the cooperative outcome, or by the creation of formal agreements that include third-party punishment mechanisms, such as the GATT. ${ }^{4}$ However, as Bagwell and Staiger (1990) argue, these schemes cannot account for the growing incidence of the use of "special protection," such as escape clause actions, VERs and AD.

3 The injury requirement also makes it more likely that one would name countries with large imports or large changes in imports since such trends are usually taken as evidence of economic harm.

4 Papers by Dixit (1987), Jensen and Thursby (1984), Mayer (1981), and Riezman (1982) explore these issues. 
To better explain the existence of special protection, Bagwell and Staiger use a simple two-country partial equilibrium model of trade in one sector with a prisoners' dilemma payoff structure. They then assume that each country's output is subject to (observed) random shocks where positive shocks lead to higher volumes of trade. In the repeated game, cooperation can be sustained by means of a credible threat to revert forever to the static Nash equilibrium in the event of any defection. Crucially, Bagwell and Staiger show that the level of cooperation, that is, the value of the cooperative tariff, depends on the volume of trade and on the variance of the shocks (i.e., the size of the import "surge"). They show that the cooperative tariff rate is increasing in both import size and variance. In other words, Bagwell and Staiger formalize Corden's (1974) argument that special protection may be a tacitly agreed method to maintain cooperation in volatile trade periods.

From an empirical perspective, the "special protection" hypothesis implies two testable outcomes. First, AD cases are more likely to be filed against a country's largest trading partners. And, second, AD cases should be more likely to be filed against those trading partners with recent surges in import volume.

\section{$\underline{\text { Strategic Use of AD - Punishment and/or Deterrence }}$}

According to Bagwell and Staiger, special protection is a (symmetric) cooperative response to a changing trade environment that allows countries to maintain cooperation in times of volatile trade volumes. Within their model, the changes in tariff levels are equilibrium responses to changes in the size or variance of imports. Yet, there are reasons to believe that there may be additional factors that should be considered when studying AD filing behavior. For example, Finger (1993) argues that the countries that use AD form a type of "club," in that they tend to apply AD against one another rather than against non-club members. Similarly, Prusa (2001) 
argues that many countries appear to file $\mathrm{AD}$ actions against countries that have previously investigated them, suggesting a type of tit-for-tat behavior. ${ }^{5}$

Both of these arguments suggest that countries may be using AD in a strategic fashion to punish defectors (or perhaps to deter defection). Without any further elaboration, however, both patterns are inconsistent with $\mathrm{AD}$ as protection against unfair trade and are outside the BagwellStaiger special protection framework. Here we suggest two extensions to the Bagwell-Staiger model that would generate the club effect and/or tit-for-tat filing in equilibrium: (i) imperfect monitoring of demand shocks and (ii) political economy incentives to misuse AD. A third possibility discussed below is that the punishment strategies are in fact evidence that countries are "out of equilibrium" (in the Bagwell-Staiger notion of cooperative equilibrium).

One extension to the Bagwell-Staiger framework would broaden the basic prisoners' dilemma game to allow for the demand shock to be unobserved. As shown by Green and Porter (1984) this type of unobservable shock can induce a cartel to enter into a "punishment" phase even if no player has deviated from the cooperative outcome. Applying the Green and Porter logic to our application generates filing patterns consistent with punishment strategies. In particular, we could consider AD users as members of a type of cartel or $c l u b$, in which monitoring the behavior of each club member is not possible. Then, when club members experience trade-related economic difficulties, they respond by filing AD cases, whether or not the named countries have actually "dumped."

A pattern of Green and Porter reversion to high duties could give rise to either direct punishment or indirect punishment. If, for example, country A's use of AD against Country B leads country B to file its own AD case against Country A, then we will observe direct punishment. For convenience we will refer to this type of behavior as "tit-for-tat" punishment

\footnotetext{
5 Messerlin and Reed (1995, p. 1573) suggest a similar effect by which the AD Code, in encouraging the standardization and spread of AD law across WTO-member countries "may tempt countries to take AD measures as disguised retaliation."
} 
even though we are intending a somewhat broader than usual interpretation of the term. ${ }^{6}$ On the other hand, if country A's use of AD against Country B leads other countries (country C, D, E, etc.) to file $\mathrm{AD}$ cases against Country $\mathrm{A}$, then we will observe indirect punishment, or what we will refer to as "club effect" punishment. Finger (1993) was the first (to our knowledge) to suggest this type of behavior and we follow his lead in referring to it as a club effect.

A second potential extension to the Bagwell-Staiger model would allow political motivations for offering protection. For instance, in the Grossman and Helpman (1994) framework politicians care not just about national welfare but also about the financial contributions they raise. They show that politicians will offer more protection than is optimal (from a national point of view) because doing so allows them to raise additional funds to finance future campaigns.

Applied to our model, Grossman-Helpman's political economy story would suggest that politics would lead governments to apply AD more aggressively than simple economics would predict. In order to deter politicians from abusing this flexibility, trading partners may want to raise the cost to applying $\mathrm{AD}$. They do so by filing their own $\mathrm{AD}$ actions in response to seeing others using $\mathrm{AD}$. In equilibrium, one would expect that politicians would design AD so only industries with a high willingness to pay for protection will file AD actions, since doing so induces other countries to respond with their own AD actions. As with the Green and Porter extension, this extension would give rise to observing AD cases being filed as indirect and/or direct punishment.

Finally, it may be the case that worldwide AD use is not in "equilibrium." That is, the heavy use of AD law during the late-1970s and early-1980s may have been too aggressive, and rather than maintaining the cooperative tariff level as implied by Bagwell and Staiger, such

6 True tit-for-tat strategies punish the original defector for only so long as she continues to defect. Instances of cooperation by the original defector are rewarded by cooperative play on the part of a true tit-for-tat player. Our tit-for-tat player reverts to the Nash equilibrium, and therefore defects, for all remaining periods following a defection. 
heavy use may have been perceived as a defection to the high protection regime. If this is the case, then recent $\mathrm{AD}$ actions might be "out of equilibrium" responses to the earlier defection. As with the above two scenarios, depending on the punishment strategy such defections could give rise to either direct or indirect punishment.

\section{Estimating the Strategic Motives for AD Filings}

In order to investigate the motives for filing $\mathrm{AD}$ cases, we have compiled a database of all $\mathrm{AD}$ cases filed from 1980 through 1998 by GATT/WTO members. The filing trends were depicted in Figure 1 and reported in Table 1 as well as discussed briefly in Section II.B. above. The most salient facts are as follows: (i) over $3500 \mathrm{AD}$ cases were filed worldwide over the 19 year period; (ii) two-thirds of the cases were filed by traditional users, although the percentage has been falling in recent years; (iii) only nine countries filed AD cases during the 1980s, but 29 countries filed AD cases during the 1990s, suggesting that many countries are beginning to catch the AD bug; and (iv) about one-fifth of the cases were filed against non-market economies.

This final point is noteworthy since the rules for determining the existence of dumping are quite different when the affected country is a non-market economy (Boltuck and Litan, 1991). As a result, the motivation for filing against a non-market economy is likely to be quite different than that for filing against a market economy. For this reason, we drop cases against non-market economies from our analysis. ${ }^{7}$

Another issue that is worth mentioning is that our data is based on aggregate filing data. In most cases and in most countries, petitions are initiated by firms, trade unions or trade associations. Our discussion of clubs and retaliation was couched in language that suggested that governments make the decisions to file, and effectively, it may be that they are, in the sense

7 We also debated whether to drop countries that are members of a preferential trade agreement (e.g., drop Mexico and Canada from U.S. filing data). Although we were concerned about preferential treatment, we were unable to gather complete data on which FTA have special rules pertaining to $\mathrm{AD}$ actions against member countries. As a result, we do not control for FTA. 
that governments communicate with the pertinent firms about the possibility of filing. On the other hand, it may be that firms themselves retaliate. See Maur (1998) for a evidence of retaliation at the industry-level. Regardless of one's preferred interpretation, we are interested in whether there is any evidence of retaliatory filings.

As discussed in the preceding section, there are four main hypotheses that we examine in our analysis of AD filing behavior. These hypotheses are: big supplier, big change in imports, tit-for-tat, and club effect. The first two are motivated by the Bagwell-Staiger model of special protection and are consistent with the view that $\mathrm{AD}$ actions are used to prevent unfair trade. The last two are outside the basic Bagwell-Staiger model and are consistent with the belief that strategic considerations influence AD actions.

The "big supplier" hypothesis is that AD cases are filed against a country's largest import suppliers (based on aggregate country data). The "big change" hypothesis is that AD cases are filed against suppliers who have the largest percentage change in imports. The tit-fortat hypothesis is that a country is more likely to file AD cases against those suppliers who previously have filed an AD case against it. For example, under the tit-for-tat hypothesis if the U.S. and Australia have filed cases against Mexico in the past, then Mexico will be more likely to file cases against the U.S. and Australia than against, say, South Korea and Venezuela. The club hypothesis is that a country is more likely to file AD cases against countries that also use $\mathrm{AD}$, regardless of whether it has been directly named in the past. Continuing with the above example, if South Korea has used AD against countries other than Mexico, under the club hypothesis Mexico would be more likely to name South Korea than Uruguay (i.e., a country that had not used $\mathrm{AD}$ at all).

Figure 2 gives a broad picture of how the four hypotheses are reflected in the data. Overall, $47 \%$ of $\mathrm{AD}$ cases are filed in a manner consistent with tit-for-tat and $62 \%$ are consistent with the club effect. Thus, it appears that these two strategic hypotheses find substantial support in the data.

Economic incentives also receive strong support. For instance, overall 99\% of AD cases are filed against big suppliers, where we have defined big suppliers as those countries with 
import shares greater than that of the median supplier. The big change hypothesis also seems reasonably consistent with the data, as $54 \%$ of $\mathrm{AD}$ cases are filed against suppliers whose percentage change in imports is greater than that of the supplier with the median percentage change.

There also appear to be substantial differences in the patterns between new and traditional users. For instance, the filing patterns of new users seem to more strongly support the strategic hypotheses, tit-for-tat and club, than those of traditional users. While new users may indeed use AD more strategically than do traditional users, this may be due to the fact that a different proportion of countries supplying new and traditional users were AD users. For instance, if all of a new user's suppliers were AD users, then we would report $100 \%$ of this country's cases were consistent with the club effect.

In order to identify the individual effects of each hypothesis, we proceed with parametric estimation of the AD filing decision. ${ }^{8}$ To do so, we model each country's decision to file an AD action against each trading partner in each year as a function of the economic and strategic incentives. Let $\mathrm{F}_{\mathrm{ijt}}$ be a binary variable that denotes whether country $\mathrm{i}$ files an AD case against country $\mathrm{j}$ in year $\mathrm{t}$. We can then express the filing decision as

$$
F_{i j t}=f\left(T F T_{i j t}, \text { Clubjt }, \text { Importsijt, \% Importsijt, All_Importsit }\right) \text {, }
$$

where TFT $\mathrm{ijt}$ denotes whether country $\mathrm{j}$ has ever filed an AD case against country i prior to year $t$, Clubjt denotes whether country $j$ is a member of the "AD club" prior to year $t$, Importsijt denotes imports from $\mathrm{j}$ to $\mathrm{i}$ at time $\mathrm{t}$, and $\% \Delta$ Importsijt denotes the percentage change in imports from $\mathrm{j}$ to $\mathrm{i}$ between $\mathrm{t}-1$ and $\mathrm{t}$. The final variable, All_Importsit, is not directly related to the proposed hypotheses but rather captures the intuition that overall filing patterns might systematically vary across users. That is, everything else equal, some users may use AD more

\footnotetext{
8 Note that Prusa and Skeath (2002) present non-parametric tests of the hypotheses presented above. The results there show variation in effects across user types and suggest that strategic motives for AD use cannot be dismissed.
} 
aggressively than other users. A natural way countries might differ in their use of AD is in their exposure to imports. Thus, the variable All_Importsit denotes country i's import in year $t$ from all sources. ${ }^{9}$

We estimate this decision function using probit. ${ }^{10}$ In Tables 2 through 5 we present the parameter estimates for the model. A different specification is presented in each table. We begin with the simplest specification (Table 2) and move to the most general specification (Table 5). In all specifications we measure the strategic hypotheses (tit-for-tat and club) using simple dummy variables. In addition, we allow the strategic incentives to vary by the level of imports; both linear and quadratic specifications are investigated. Moreover, in specifications B and D (Tables 3 and 5) we allow the hypotheses to have different impacts for new or traditional users. In all specifications we estimate (but do not report) year effects.

Finally, we note that in each table we report two sets of results, one based on data for all years and the other based on data only for each country's first three years of AD use. The restricted dataset, including information only on each country's first three years of AD activity, was constructed in order to control for potential endogeneity problems with respect to our titfor-tat and club effect tests. The following example clarifies our concern.

Suppose that in 1981 the U.S. filed an AD case against Mexico. Next assume that Mexico filed an AD case against the U.S. in 1983. According to our definitions we would say Mexico's filing was consistent with tit-for-tat (and also the club effect). Now, suppose that the U.S. filed a case against Mexico in 1986. Once again, according to our definitions we would say this filing is consistent with tit-for-tat (and the club effect). But, this tit-for-tat finding was the result of Mexico responding to the U.S.'s earlier filing, and hence is endogenous. In this scenario, our measures of the tit-for-tat and club effects would both be distorted by such endogeneity. In an attempt to mitigate this potential problem, we chose to report statistics on

\footnotetext{
9 Miranda, Torres, and Ruiz (1998) suggest that small importers use AD more aggressively.

10 We also estimated using logit and found that the results are not significantly different.
} 
only the first three years of each country's use of $\mathrm{AD}$ in addition to reporting results for the full dataset.

Given that the results do differ somewhat across the two datasets we will need to keep in mind that that the results based on the "first three years" data are probably best interpreted as capturing the incentives during a country's initial years of using AD. The results based on the "all years" data should be interpreted as capturing a country's long-run strategic use of AD.

Our most straightforward specification is presented in Table 2. In this specification we constrain the strategic and economic motives to be the same for new and traditional users. The non-linear nature of the probit estimates makes it difficult to easily interpret the economic significance of the coefficients. Thus, to address the economic significance, we also calculate the "change in probability" implied by the estimates and report these results within our discussion below. ${ }^{11}$

In reviewing the results from our simplest specification, Specification A, as reported in Table 2, we see first that almost all included variables are statistically significant. This result holds true for the tests run on both datasets and for both the linear and quadratic forms of our model. Importantly, there is support here for all four of our hypotheses, both strategic and economic. The largest observed effect is from the "big supplier" hypothesis but both strategic hypotheses receive considerable support in the data. Curiously, the "import surge" hypothesis, measured by the impact of changes in import volumes, appears to have a significant negative

11 The "economic" impact estimates are not reported in the text for all regressions or variables. They are available from the authors upon request. 
(albeit small) effect on AD use. This result appears in all specifications of our model and suggests that our hypothesis related to import surges is not upheld in the data. ${ }^{12}$

Looking more closely at the impact of the strategic incentives, we note that the club effect is relatively large. Across the four regressions reported in Table 2, AD club members are about $15-20 \%$ more likely than non-club members to be investigated by other countries. ${ }^{13}$ Second, and surprisingly, the tit-for-tat (TFT) effect appears with the wrong sign in every regression in this specification. Our hypotheses above suggested that TFT retaliation incentives would increase the likelihood of $\mathrm{AD}$ actions and we therefore expected a positive coefficient on this variable. We note, however, that the estimated TFT impact is quite small, lowering the probability of being named by only about $1 \%$.

The negative sign on the TFT variable is sufficiently curious to warrant further investigation. In particular, it is possible that the unanticipated sign results from the fact that Specification A does not allow new and traditional users to differ in their strategic and economic incentives to use AD. If the two types of users do differ systematically in their filing patterns, the parameters reported in Table 2 would reflect the weighted average of the traditional and new users impact. Thus, the results from Specification A may be significantly skewed and may not accurately capture either the strategic or economic incentives for AD use.

In Specifications B, C, and D we address this issue by allowing for separate new and traditional user estimates. The three specifications incorporate different levels of variation

12 In later specifications ( $\mathrm{C}$ and $\mathrm{D}$, see below) we allow the economic impact parameters to vary according to type of user (traditional versus new). In those specifications, the "percentage change in imports" variable is still consistently estimated with a negative coefficient although the measured effect is smaller and less significant for new users than for traditional users.

13 As is standard practice, evaluation of the club and TFT effects are done at the mean values of all other exogenous variables. As we will discuss below, this average impact may not reflect the impact at other points in the distribution. 
across the user types. In particular, in Specification B (Table 3) we allow the strategic effects to vary by type of user but we hold the Bagwell-Staiger economic effects common across the users. In Specification C we do the opposite, allowing the Bagwell-Staiger economic effects to vary by type of user but holding the strategic effects common across users (Table 4). Finally, in Specification D we allow all the parameters to vary by type of user (Table 5).

Given our interest in strategic filing issues, specification B (reported in Table 3) is our preferred specification. As in Specification A, almost all of the parameters are statistically significant. In particular, there is statistical support for all four AD use hypotheses. We also see, as in Specification A, that there is strong support for the "big supplier" hypothesis and that the effect of this parameter on one's chance of being named in an AD case is quite large. At the same time, the "import surge" hypothesis receives much weaker support and appears with the wrong sign, as discussed above.

Importantly, distinguishing between new and traditional users in this specification allows us to refine our understanding of tit-for-tat and club incentives. In particular, the estimates indicate that the TFT incentive for traditional users ranges from moderate (in the all years dataset) to strong (in the first three years dataset). Traditional users are between $0.5 \%$ and $5 \%$ more likely to file $\mathrm{AD}$ cases against countries that have filed against them in the past. By contrast, we find that the TFT effect of new users is consistently negative and strongly significant in the first three years dataset. The change in probability in this case is small, but the results indicate that new users are about $0.5 \%$ less likely to file against countries that had filed against them (in the first three years or overall). These contrasting results suggest that our concerns about the results in Specification A were justified and that it is important to estimate separate effects for traditional and new users.

In order to investigate further this variation across user types in the incentives to use AD, we look at the extent to which strategic incentives vary both by user type and by level of imports. We find that the TFT and club effects vary considerably with the size of the supplier, for each type of user. To illustrate this finding, we plot the probability of naming a country in an AD case against the dollar value of imports from the source country. We do this for both 
traditional and new users for the linear version of our model for both the "all years" and "first three years" datasets in Figures 3 through 6. For example, Figure 3 shows the estimated filing behavior of traditional users using the linear specification and the "all years" dataset. In the figure, we separately plot the incentive to name a country that is not a club member ("base" curve), a country that is a club member, and a country that is a club member that has also used AD against a traditional user.

Precisely as one would expect, we see in all of the plots in Figures 3 through 6 that the probability of naming a country is increasing in imports. Exactly how the probability varies depends, however, on the different strategic incentives. It also depends on the type of user under consideration.

For traditional users over all years (Figure 3), we see that the probability of naming a non-club member (the base curve) is essentially zero for low import values, but increases quite sharply as import values rise. Being a club member, however, significantly increases the likelihood of being named at small import values. Interestingly, the club effect impact dissipates and eventually becomes negative at large import values. In other words, it appears that being a club member is especially costly if the country is small. This finding suggests that the smaller a country is, the more likely it is that other AD users punish it with AD protection. The TFT effect is larger than the club effect only for very small import values and in general reduces the chance of being named. We interpret this result as likely indicating that TFT incentives may be correlated with country-specific variables that on average reduce the chance of being named. ${ }^{14}$ Overall, the "all years" results indicate reasonably strong support for the club hypothesis but only modest support for the tit-for-tat hypothesis for traditional users.

By contrast, when we look at the behavior of traditional users using the linear specification based on the "first three years" dataset we find quite strong support for both the

14 This result may also be capturing some of the "fear of retaliation" incentives identified in Blonigen and Bown (2001), although their work is based solely on U.S. antidumping filing behavior. 
club and TFT hypotheses (Figure 4). For small import volumes, club and TFT each increase the likelihood of being named by about 20 percentage points. To be precise, the tit-for-tat effect is economically significant, increasing the likelihood of being named upwards of $30-40 \%$ (at low import values). As we saw in Figure 3, club and TFT both dampen the import size effect for large importers. Ultimately, beyond a critical size (about \$27 million), TFT incentives do not appear important; similar club incentives become unimportant beyond about $\$ 17$ million.

Nevertheless, the estimates indicate that traditional users' filing patterns in this restricted sample are heavily influenced by strategic considerations.

In Figures 5 and 6 we look at the behavior of new users using the linear specification based on the "all years" and "first three years" datasets, respectively. For new users, the two figures tell very similar stories. For both datasets the club effect is economically large and significant, increasing the likelihood of being investigated by about $20 \%$ at low import volumes. As we saw was true for traditional users, this effect dissipates as import volume grows. For both datasets we also find TFT incentives to be negative and small for the new users.

Combining the insights of all four figures, we conclude that traditional and new users do have significantly different patterns of AD use. Thus, it appears that the probit results based on Specification A are misleading because they constrain a single parameter to capture the incentives of these two very different sets of users. New users appear to have a more pronounced club effect and traditional users appear to be more influenced by tit-for-tat (at least in the restricted sample). Finally, given the consistency of the results across new and traditional users and across datasets, we believe that strategic considerations are outweighed by economic factors in motivating AD cases filed against big suppliers.

Our third specification of the model, Specification C (reported in Table 4), allows the parameters associated with the economic hypotheses to vary across users while constraining the parameters associated with the strategic hypotheses to be the same for both new and traditional users. As in the earlier specifications, we find considerable statistical significance for most variables across both types of users. The exception is that the percentage change in import parameters is insignificant for new users (and relatively small in magnitude for traditional 
users). Notice, however, that unlike the Specification B results in which we saw a clear difference between new and traditional users in the strategic incentives, there is very little difference here between the estimated impact of economic factors for the two types of users.

Finally, in specification D (Table 5) we allow both strategic and economic hypotheses to vary by user. This is the most flexible specification, but we are a bit concerned that there is insufficient variation among the exogenous variables. Thus, we may not be meaningfully identifying the separate strategic and economic incentives. We note that the TFT impact estimated here is very similar to that estimated in Specification B (Table 3). Namely, traditional users filing patterns are consistently estimated to indicate the presence of positive club and TFT incentives. Both effects increase the likelihood that traditional users will file AD actions. New users demonstrate a strong club effect, but a very small TFT incentive. In other words, the club effect is more pronounced for new users, but offsetting this stronger club effect is a negative titfor-tat effect.

\section{Concluding Comments}

The worldwide upsurge in AD use in the past two decades has begun to receive considerable attention. Concerns have arisen in part because the increased antidumping activity is evident not only in the number of cases filed annually but also in the range of countries now actively using AD policies. With the intensified use of this WTO-legal protection comes a need to identify the motives underlying the changes in patterns of behavior. In particular, it is increasingly difficult to argue that the changes in $\mathrm{AD}$ use reflect only an increase in unfair trading behavior that has taken hold since 1980 .

Our findings suggest that antidumping use is not just about protecting domestic industries from the unfair trade behavior of foreign entities. Although we find strong support for the economic hypothesis that $\mathrm{AD}$ actions are directed at big suppliers, we find far weaker evidence that $\mathrm{AD}$ actions are filed against importers with recent surges in their import volume. If antidumping filings were primarily aimed at combating unfair trading practices, we would 
expect that suppliers with large import surges would generally be the targets of those filings. Our evidence implies that this is not the case and that there are other incentives that play a significant role in national use of AD policy. ${ }^{15}$

Following recent literature that suggests that strategic, particularly retaliatory, incentives may play a role in $\mathrm{AD}$ use, we test for evidence of such behavior in case filings from the last two decades. In our results, we find evidence of a strong strategic component in the use of AD worldwide. Further, there seems to be ample evidence from our analysis that the traditional and new users of $\mathrm{AD}$ employ the antidumping laws in different ways. We observe strong strategic incentives for AD use particularly (but not exclusively) for traditional users, who show evidence of using $\mathrm{AD}$ for both club effect and tit-for-tat reasons. New users have a more significant club effect, but a negative tit-for-tat effect that mutes the club effect somewhat. In addition, our results suggest that strategic considerations are outweighed by economic factors in motivating AD cases filed against big suppliers.

Overall, our evidence is consistent with results beginning to be reported elsewhere in the literature. The econometric evidence provided here bolsters the results of the non-parametric tests performed in our earlier work (Prusa and Skeath, 2002), for example, and we find evidence of the type of retaliatory behavior that Blonigen and Bown (2001) argue may reduce the likelihood of U.S. AD cases being filed against certain countries. Indeed, we provide evidence to support Messerlin and Reed's (1995) contention that AD measures may be used as a form of "disguised retaliation." Our findings reject the notion that the rise in AD activity is solely explained by an increase in unfair trading and support the view that strategic incentives play a critical role in the motivation of individual countries to file AD complaints against their suppliers.

15 In future research we are also interested in analyzing whether the patterns we find based on filing data are confirmed in if we based our on duties levied or measures taken (i.e., an outcome based measure of protection). 


\section{References}

Bagwell, Kyle and Robert Staiger, "A Theory of Managed Trade," American Economic Review 80 (1990): 779-95.

Blonigen, Bruce A. and Chad P. Bown, “Antidumping and Retaliation Threats," NBER Working Paper No. 8576, October 2001.

Boltuck, Richard and Robert E. Litan (eds.), Down in the Dumps: Administration of the Unfair Trade Laws, Washington, DC: Brookings Institute, 1991.

Brander, James A. and Paul Krugman, “A 'Reciprocal Dumping’ Model of International Trade,” Journal of International Economics 15 (1983): 313-21.

Corden, W. Max, Trade Policy and Economic Welfare, Oxford: Clarendon Press, 1974.

Dixit, Avinash K., “Strategic Aspects of Trade Policy,” in Truman F. Bewley (ed.), Advances in Economic Theory: Fifth World Congress, New York: Cambridge University Press, 1987, $329-62$.

Ethier, Wilfred J., “Dumping,” Journal of Political Economy 90 (1982): 487-506.

Finger, J. Michael (ed.), Antidumping, Ann Arbor, MI: University of Michigan Press, 1993.

Finger, J. Michael and Kwok-Chiu Fung, "Will GATT Enforcement Control Antidumping?”, Journal of Economic Integration 9 (1994): 198-213.

Finger, J. Michael, H. Keith Hall, and Douglas R. Nelson, “The Political Economy of Administered Protection," American Economic Review 72 (1982): 452-66.

Fischer, Ronald D. and Thomas J. Prusa, "Contingent Protection as Better Insurance," Review of International Economics 11 (2003): 758-769.

Green, Edward J. and Robert H. Porter, "Noncooperative Collusion Under Imperfect Price Information," Econometrica 52 (1984): 87-100. 
Grossman, Gene and Elhanan Helpman, "Protection for Sale," American Economic Review 84 (1994): 833-50.

Hansen, Wendy and Thomas J. Prusa, "The Road Most Traveled: The Rise of Title VII Protection," The World Economy 18 (1995): 295-313. , "Cumulation and ITC Decision-Making: The Sum of the Parts is Greater than the Whole," Economic Inquiry 34 (1996): 746-69.

Hufbauer, Gary, “Antidumping: A Look at U.S. Experience - Lessons for Indonesia.” Report to the Ministry of Industry and Trade, Republic of Indonesia, http://www.iie.com/papers/hufbauer0899-1.htm, August 1999.

Hufbauer, Gary, and Kimberly Elliott, Measuring the Costs of Protection in the United States, Washington, DC: Institute for International Economics, 1994.

Jensen, Richard and Marie Thursby, "Free Trade: Two Noncooperative Approaches.” Ohio State University Working Paper, 1984.

Mastel, Greg, Antidumping Laws and the U.S. Economy, Armonk, NY: M.E. Sharpe, 1998. Maur, Jean-Christophe, "Echoing antidumping cases: Regulatory competitors, imitation and cascading protection," World Competition, 21 (1998): 51-84.

Mayer, Wolfgang, "Theoretical Considerations on Negotiated Tariff Adjustments," Oxford Economic Papers 33 (1981): 135-53.

McDonald, Brian, The World Trading System: The Uruguay Round and Beyond, New York: St. Martin’s Press, 1998.

Messerlin, Patrick A. and Geoffrey Reed, "Antidumping Policies in the United States and the European Community," The Economic Journal 105 (1995): 1565-75.

Miranda, Jorge, Raul A. Torres and Mario Ruiz, “The International Use of Antidumping: 19871997," Journal of World Trade 32 (1998): 5-71. 
Prusa, Thomas J., "Why Are So Many Antidumping Petitions Withdrawn?”, Journal of International Economics 33 (1992): 1-20. , "On the Spread and Impact of Antidumping," Canadian Journal of Economics 34 (2001): 591-611.

Prusa, Thomas J. and Susan Skeath, "The Economic and Strategic Motives for Antidumping Filings," Weltwirtschaftliches Archiv, 138 (2002): 389-413.

Riezman, Raymond, "Tariff Retaliation from a Strategic Viewpoint," Southern Economic Journal 48 (1982): 583-93.

Staiger, Robert W. and Frank A. Wolak, "The Effect of Domestic Antidumping Law in the Presence of Foreign Monopoly," Journal of International Economics 32 (1991): 265-87. 
Table 1. Antidumping Activity: 1980s vs. 1990s

\begin{tabular}{|c|c|c|c|c|}
\hline & \multicolumn{2}{|c|}{$\begin{array}{l}\text { Percent of total AD } \\
\text { cases (worldwide) }\end{array}$} & $\begin{array}{c}\text { Year country began } \\
\text { using AD } \\
\text { (GATT/WTO reports) }\end{array}$ & $\begin{array}{l}\text { No. AD actions against } \\
\text { country prior to the } \\
\text { adoption of own AD statute }\end{array}$ \\
\hline USA & $28.2 \%$ & $16.4 \%$ & -- & --- \\
\hline Australia & $25.5 \%$ & $16.0 \%$ & --- & --- \\
\hline Canada & $21.3 \%$ & $6.5 \%$ & --- & --- \\
\hline EU & $19.8 \%$ & $14.6 \%$ & --- & --- \\
\hline New Zealand & $0.7 \%$ & $2.4 \%$ & --- & --- \\
\hline Finland & $1.4 \%$ & $0.1 \%$ & --- & --- \\
\hline Mexico & $2.6 \%$ & $7.8 \%$ & 1987 & 10 \\
\hline South Korea & $0.4 \%$ & $2.6 \%$ & 1985 & 39 \\
\hline Brazil & $0.1 \%$ & $5.5 \%$ & 1988 & 55 \\
\hline Argentina & & $6.3 \%$ & 1991 & 16 \\
\hline South Africa & & $6.1 \%$ & 1994 & 20 \\
\hline India & & $4.2 \%$ & 1992 & 16 \\
\hline Turkey & & $1.6 \%$ & 1993 & 15 \\
\hline Colombia & & $1.2 \%$ & 1991 & 4 \\
\hline Poland & & $1.2 \%$ & 1991 & 43 \\
\hline Israel & & $1.1 \%$ & 1993 & 13 \\
\hline Indonesia & & $1.1 \%$ & 1996 & 31 \\
\hline Venezuela & & $1.0 \%$ & 1993 & 18 \\
\hline Peru & & $0.9 \%$ & 1994 & 1 \\
\hline Malaysia & & $0.7 \%$ & 1995 & 32 \\
\hline Philippines & & $0.7 \%$ & 1993 & 9 \\
\hline Chile & & $0.5 \%$ & 1993 & 5 \\
\hline Egypt & & $0.3 \%$ & 1997 & 7 \\
\hline Thailand & & $0.3 \%$ & 1993 & 35 \\
\hline Costa Rica & & $0.3 \%$ & 1996 & 1 \\
\hline Trin-Tobago & & $0.2 \%$ & 1996 & 3 \\
\hline Japan & & $0.2 \%$ & 1991 & 164 \\
\hline Czechoslovakia & & $0.1 \%$ & 1998 & 69 \\
\hline Nicaragua & & $0.1 \%$ & 1998 & 2 \\
\hline Panama & & $0.1 \%$ & 1998 & 0 \\
\hline Singapore & & $0.1 \%$ & 1994 & 34 \\
\hline Ecuador & & $0.1 \%$ & 1998 & 2 \\
\hline Guatemala & & $0.1 \%$ & 1996 & 0 \\
\hline TOTAL \# & 1401 & 2113 & & \\
\hline
\end{tabular}


Table 2. Probit Regression - Specification A

\begin{tabular}{|c|c|c|c|c|}
\hline & $\begin{array}{c}\text { Linear } \\
\text { All years }\end{array}$ & $\begin{array}{l}\text { Quadratic } \\
\text { All years }\end{array}$ & $\begin{array}{c}\text { Linear } \\
\text { First } 3 \text { years }\end{array}$ & $\begin{array}{l}\text { Quadratic } \\
\text { First } 3 \text { years }\end{array}$ \\
\hline Tit-for-Tat & $\begin{array}{l}-0.103 \\
{[0.069]}\end{array}$ & $\begin{array}{c}-0.185 \\
{[0.073]^{*}}\end{array}$ & $\begin{array}{c}-0.268 \\
{[0.134]^{*}}\end{array}$ & $\begin{array}{c}-0.323 \\
{[0.153]^{*}}\end{array}$ \\
\hline Club Effect & $\begin{array}{c}1.422 \\
{[0.058]^{* *}}\end{array}$ & $\begin{array}{c}1.433 \\
{[0.060]^{* *}}\end{array}$ & $\begin{array}{c}1.501 \\
{[0.107]^{* *}}\end{array}$ & $\begin{array}{c}1.491 \\
{[0.116]^{* *}}\end{array}$ \\
\hline TFT x Imports & $\begin{array}{c}-15.362 \\
{[5.163]^{* *}}\end{array}$ & $\begin{array}{l}-17.262 \\
{[7.883]^{*}}\end{array}$ & $\begin{array}{c}-5.48 \\
{[21.675]}\end{array}$ & $\begin{array}{c}-31.604 \\
{[54.846]}\end{array}$ \\
\hline Club Effect x Imports & $\begin{array}{c}-32.722 \\
{[5.878]^{* *}}\end{array}$ & $\begin{array}{c}-92.264 \\
{[9.596]^{* *}}\end{array}$ & $\begin{array}{c}-63.186 \\
{[23.165]^{* *}}\end{array}$ & $\begin{array}{c}-139.455 \\
{[55.480]^{*}}\end{array}$ \\
\hline TFT x Imports2 & & $\begin{array}{c}82.054 \\
{[40.986]^{*}}\end{array}$ & & $\begin{array}{c}1,889.74 \\
{[2,015.892]}\end{array}$ \\
\hline Club Effect x Imports2 & & $\begin{array}{c}1,177.68 \\
{[101.478]^{* *}}\end{array}$ & & $\begin{array}{c}2,071.59 \\
{[2,089.293]}\end{array}$ \\
\hline Imports & $\begin{array}{c}60.577 \\
{[3.418]^{* *}}\end{array}$ & $\begin{array}{c}139.025 \\
{[6.570]^{* *}}\end{array}$ & $\begin{array}{c}103.205 \\
{[10.952]^{* *}}\end{array}$ & $\begin{array}{c}253.893 \\
{[22.824]^{* *}}\end{array}$ \\
\hline Imports2 & & $\begin{array}{c}-1,336.18 \\
{[94.662]^{* *}}\end{array}$ & & $\begin{array}{c}-4,904.17 \\
{[694.949]^{* *}}\end{array}$ \\
\hline \%Delta imports & $\begin{array}{c}-0.013 \\
{[0.005]^{*}}\end{array}$ & $\begin{array}{c}-0.012 \\
{[0.005]^{*}}\end{array}$ & $\begin{array}{c}-0.044 \\
{[0.020]^{*}}\end{array}$ & $\begin{array}{c}-0.041 \\
{[0.020]^{*}}\end{array}$ \\
\hline \%Delta Imports2 & & $\begin{array}{c}0 \\
{[0.000]^{*}}\end{array}$ & & $\begin{array}{c}0 \\
{[0.000]^{*}}\end{array}$ \\
\hline Imports - All Suppliers & $\begin{array}{c}-0.037 \\
{[0.031]}\end{array}$ & $\begin{array}{c}-0.419 \\
{[0.075]^{* *}}\end{array}$ & $\begin{array}{c}-1.13 \\
{[0.245]^{* *}}\end{array}$ & $\begin{array}{c}-3.236 \\
{[0.791]^{* *}}\end{array}$ \\
\hline Imports All Suppliers2 & & $\begin{array}{c}0.106 \\
{[0.022]^{* *}}\end{array}$ & & $\begin{array}{c}2.482 \\
{[1.095]^{*}}\end{array}$ \\
\hline Constant & $\begin{array}{c}-1.829 \\
{[0.106]^{* *}}\end{array}$ & $\begin{array}{c}-1.846 \\
{[0.111]^{* *}}\end{array}$ & $\begin{array}{c}-1.629 \\
{[0.124]^{* *}}\end{array}$ & $\begin{array}{c}-1.553 \\
{[0.131]^{* *}}\end{array}$ \\
\hline Observations & 20684 & 20684 & 7088 & 7088 \\
\hline
\end{tabular}


Table 3. Probit Regression - Specification B

\begin{tabular}{|c|c|c|c|c|}
\hline & $\begin{array}{c}\text { Linear } \\
\text { All years }\end{array}$ & $\begin{array}{l}\text { Quadratic } \\
\text { All years }\end{array}$ & $\begin{array}{c}\text { Linear } \\
\text { First } 3 \text { years }\end{array}$ & $\begin{array}{l}\text { Quadratic } \\
\text { First } 3 \text { years }\end{array}$ \\
\hline Traditional User x TFT & $\begin{array}{c}0.092 \\
{[0.110]}\end{array}$ & $\begin{array}{c}0.024 \\
{[0.115]}\end{array}$ & $\begin{array}{c}0.868 \\
{[0.403]^{*}}\end{array}$ & $\begin{array}{c}0.893 \\
{[0.409]^{*}}\end{array}$ \\
\hline Traditional User x Club Effect & $\begin{array}{c}1.633 \\
{[0.080]^{* *}}\end{array}$ & $\begin{array}{c}1.672 \\
{[0.082]^{* *}}\end{array}$ & $\begin{array}{c}1.121 \\
{[0.300]^{* *}}\end{array}$ & $\begin{array}{c}1.136 \\
{[0.304]^{* *}}\end{array}$ \\
\hline New User x TFT & $\begin{array}{c}-0.114 \\
{[0.087]}\end{array}$ & $\begin{array}{c}-0.175 \\
{[0.090]}\end{array}$ & $\begin{array}{c}-0.369 \\
{[0.141]^{* *}}\end{array}$ & $\begin{array}{c}-0.467 \\
{[0.161]^{* *}}\end{array}$ \\
\hline New User x Club Effect & $\begin{array}{c}1.224 \\
{[0.073]^{* *}}\end{array}$ & $\begin{array}{c}1.221 \\
{[0.075]^{* *}}\end{array}$ & $\begin{array}{c}1.527 \\
{[0.113]^{* *}}\end{array}$ & $\begin{array}{c}1.515 \\
{[0.122]^{* *}}\end{array}$ \\
\hline TFT x Imports & $\begin{array}{c}-16.547 \\
{[5.248]^{* *}}\end{array}$ & $\begin{array}{c}-19.121 \\
{[7.994]^{*}}\end{array}$ & $\begin{array}{c}-7.943 \\
{[21.968]}\end{array}$ & $\begin{array}{c}-21.276 \\
{[55.040]}\end{array}$ \\
\hline Club Effect x Imports & $\begin{array}{c}-35.93 \\
{[5.932]^{* *}}\end{array}$ & $\begin{array}{c}-99.2 \\
{[9.667]^{* *}}\end{array}$ & $\begin{array}{c}-66.537 \\
{[23.211]^{* *}}\end{array}$ & $\begin{array}{c}-147.309 \\
{[55.532]^{* *}}\end{array}$ \\
\hline TFT x Imports2 & & $\begin{array}{c}85.269 \\
{[41.247]^{*}}\end{array}$ & & $\begin{array}{c}1,536.12 \\
{[2,018.725]}\end{array}$ \\
\hline Club Effect x Imports2 & & $\begin{array}{c}1,236.86 \\
{[102.304]^{* *}}\end{array}$ & & $\begin{array}{c}2,227.65 \\
{[2,089.915]}\end{array}$ \\
\hline Imports & $\begin{array}{c}62.923 \\
{[3.452]^{* *}}\end{array}$ & $\begin{array}{c}144.571 \\
{[6.657]^{* *}}\end{array}$ & $\begin{array}{c}104.597 \\
{[10.991]^{* *}}\end{array}$ & $\begin{array}{c}257.372 \\
{[22.946]^{* *}}\end{array}$ \\
\hline Imports2 & & $\begin{array}{c}-1,391.50 \\
{[95.583]^{* *}}\end{array}$ & & $\begin{array}{c}-4,978.62 \\
{[699.143]^{* *}}\end{array}$ \\
\hline$\%$ Delta imports & $\begin{array}{c}-0.013 \\
{[0.005]^{* *}}\end{array}$ & $\begin{array}{c}-0.012 \\
{[0.005]^{*}}\end{array}$ & $\begin{array}{c}-0.044 \\
{[0.020]^{*}}\end{array}$ & $\begin{array}{c}-0.042 \\
{[0.020]^{*}}\end{array}$ \\
\hline \%Delta Imports2 & & $\begin{array}{c}0 \\
{[0.000]^{*}}\end{array}$ & & $\begin{array}{c}0 \\
{[0.000]^{*}}\end{array}$ \\
\hline Imports - All Suppliers & $\begin{array}{c}-0.111 \\
{[0.034]^{* *}}\end{array}$ & $\begin{array}{c}-0.555 \\
{[0.079]^{* *}}\end{array}$ & $\begin{array}{c}-1.202 \\
{[0.251]^{* *}}\end{array}$ & $\begin{array}{c}-3.114 \\
{[0.794]^{* *}}\end{array}$ \\
\hline Imports All Suppliers2 & & $\begin{array}{c}0.124 \\
{[0.022]^{* *}}\end{array}$ & & $\begin{array}{c}2.142 \\
{[1.107]}\end{array}$ \\
\hline Constant & $\begin{array}{c}-1.825 \\
{[0.107]^{* *}}\end{array}$ & $\begin{array}{c}-1.833 \\
{[0.113]^{* *}}\end{array}$ & $\begin{array}{c}-1.631 \\
{[0.125]^{* *}}\end{array}$ & $\begin{array}{c}-1.565 \\
{[0.132]^{* *}}\end{array}$ \\
\hline Observations & 20684 & 20684 & 7088 & 7088 \\
\hline
\end{tabular}


Table 4. Probit Regression - Specification C

\begin{tabular}{|c|c|c|c|c|}
\hline & $\begin{array}{c}\text { Linear } \\
\text { All years }\end{array}$ & $\begin{array}{l}\text { Quadratic } \\
\text { All years }\end{array}$ & $\begin{array}{c}\text { Linear } \\
\text { First } 3 \text { years }\end{array}$ & $\begin{array}{l}\text { Quadratic } \\
\text { First } 3 \text { years }\end{array}$ \\
\hline Tit-for-Tat & $\begin{array}{c}-0.105 \\
{[0.069]}\end{array}$ & $\begin{array}{c}-0.169 \\
{[0.074]^{*}}\end{array}$ & $\begin{array}{l}-0.239 \\
{[0.136]}\end{array}$ & $\begin{array}{c}-0.531 \\
{[0.167]^{* *}}\end{array}$ \\
\hline Club Effect & $\begin{array}{c}1.422 \\
{[0.058]^{* *}}\end{array}$ & $\begin{array}{c}1.422 \\
{[0.060]^{* *}}\end{array}$ & $\begin{array}{c}1.466 \\
{[0.107]^{* *}}\end{array}$ & $\begin{array}{c}1.444 \\
{[0.117]^{* *}}\end{array}$ \\
\hline TFT x Imports & $\begin{array}{c}-15.377 \\
{[5.179]^{* *}}\end{array}$ & $\begin{array}{l}-17.089 \\
{[8.064]^{*}}\end{array}$ & $\begin{array}{l}-16.553 \\
{[22.458]}\end{array}$ & $\begin{array}{c}77.365 \\
{[63.465]}\end{array}$ \\
\hline Club Effect x Imports & $\begin{array}{c}-32.605 \\
{[5.894]^{* *}}\end{array}$ & $\begin{array}{c}-91.968 \\
{[9.679]^{* *}}\end{array}$ & $\begin{array}{c}-32.839 \\
{[26.418]}\end{array}$ & $\begin{array}{c}-222.225 \\
{[83.002]^{* *}}\end{array}$ \\
\hline TFT x Imports2 & & $\begin{array}{c}91.023 \\
{[40.954]^{*}}\end{array}$ & & $\begin{array}{c}-2,900.63 \\
{[2,573.625]}\end{array}$ \\
\hline Club Effect x Imports2 & & $\begin{array}{c}1,221.62 \\
{[102.898]^{* *}}\end{array}$ & & $\begin{array}{c}13,050.37 \\
{[6,149.566]^{*}}\end{array}$ \\
\hline Traditional User x Imports & $\begin{array}{c}60.54 \\
{[3.446]^{* *}}\end{array}$ & $\begin{array}{c}145.988 \\
{[6.936]^{* *}}\end{array}$ & $\begin{array}{c}125.591 \\
{[14.159]^{* *}}\end{array}$ & $\begin{array}{c}308.348 \\
{[32.491]^{* *}}\end{array}$ \\
\hline Traditional User x Imports2 & & $\begin{array}{c}-1,411.83 \\
{[97.939]^{* *}}\end{array}$ & & $\begin{array}{c}-5,955.52 \\
{[915.737]^{* *}}\end{array}$ \\
\hline Traditional User x \%Delta Imports & $\begin{array}{c}-0.051 \\
{[0.022]^{*}}\end{array}$ & $\begin{array}{c}-0.052 \\
{[0.024]^{*}}\end{array}$ & $\begin{array}{c}-0.086 \\
{[0.060]}\end{array}$ & $\begin{array}{c}0.68 \\
{[0.229]^{* *}}\end{array}$ \\
\hline Traditional User x \%Delta Imports2 & & $\begin{array}{c}0 \\
{[0.000]}\end{array}$ & & $\begin{array}{c}-0.966 \\
{[0.295]^{* *}}\end{array}$ \\
\hline New User x Imports & $\begin{array}{c}60.309 \\
{[4.303]^{* *}}\end{array}$ & $\begin{array}{c}128.926 \\
{[7.678]^{* *}}\end{array}$ & $\begin{array}{c}72.991 \\
{[16.780]^{* *}}\end{array}$ & $\begin{array}{c}336.01 \\
{[67.138]^{* *}}\end{array}$ \\
\hline New User x Imports2 & & $\begin{array}{c}-1,392.98 \\
{[103.353]^{* *}}\end{array}$ & & $\begin{array}{c}-15,861.96 \\
{[5,857.828]^{* *}}\end{array}$ \\
\hline New User x \%Delta Imports & $\begin{array}{l}-0.008 \\
{[0.005]}\end{array}$ & $\begin{array}{l}-0.008 \\
{[0.005]}\end{array}$ & $\begin{array}{l}-0.036 \\
{[0.021]}\end{array}$ & $\begin{array}{l}-0.034 \\
{[0.039]}\end{array}$ \\
\hline New User x \%Delta Imports2 & & $\begin{array}{c}0 \\
{[0.000]}\end{array}$ & & $\begin{array}{c}0 \\
{[0.002]}\end{array}$ \\
\hline Imports - All Suppliers & $\begin{array}{c}-0.032 \\
{[0.032]}\end{array}$ & $\begin{array}{c}-0.461 \\
{[0.077]^{* *}}\end{array}$ & $\begin{array}{c}-1.28 \\
{[0.264]^{* *}}\end{array}$ & $\begin{array}{c}-3.002 \\
{[0.817]^{* *}}\end{array}$ \\
\hline Imports All Suppliers2 & & $\begin{array}{c}0.108 \\
{[0.022]^{* *}}\end{array}$ & & $\begin{array}{c}1.536 \\
{[1.180]}\end{array}$ \\
\hline Constant & $\begin{array}{c}-1.825 \\
{[0.106]^{* *}}\end{array}$ & $\begin{array}{c}-1.848 \\
{[0.112]^{* *}}\end{array}$ & $\begin{array}{c}-1.656 \\
{[0.128]^{* *}}\end{array}$ & $\begin{array}{c}-1.554 \\
{[0.143]^{* *}}\end{array}$ \\
\hline Observations & 20684 & 20684 & 7088 & 7088 \\
\hline
\end{tabular}


Table 5. Probit Regression - Specification D

\begin{tabular}{|c|c|c|c|c|}
\hline & $\begin{array}{c}\text { Linear } \\
\text { All years }\end{array}$ & $\begin{array}{l}\text { Quadratic } \\
\text { All years }\end{array}$ & $\begin{array}{c}\text { Linear } \\
\text { First } 3 \text { years }\end{array}$ & $\begin{array}{l}\text { Quadratic } \\
\text { First } 3 \text { years }\end{array}$ \\
\hline Traditional User x TFT & $\begin{array}{c}0.101 \\
{[0.111]}\end{array}$ & $\begin{array}{c}0.038 \\
{[0.122]}\end{array}$ & $\begin{array}{c}0.506 \\
{[0.714]}\end{array}$ & $\begin{array}{c}0.442 \\
{[0.774]}\end{array}$ \\
\hline Traditional User x Club Effect & $\begin{array}{c}1.667 \\
{[0.080]^{* *}}\end{array}$ & $\begin{array}{c}1.718 \\
{[0.084]^{* *}}\end{array}$ & $\begin{array}{c}0.727 \\
{[0.405]}\end{array}$ & $\begin{array}{c}0.634 \\
{[0.470]}\end{array}$ \\
\hline Traditional User x TFT x Imports & $\begin{array}{l}-12.293 \\
{[5.401]^{*}}\end{array}$ & $\begin{array}{l}-15.335 \\
{[9.526]}\end{array}$ & $\begin{array}{l}-450.106 \\
{[457.990]}\end{array}$ & $\begin{array}{c}-623.843 \\
{[865.514]}\end{array}$ \\
\hline Traditional User x Club Effect x Imports & $\begin{array}{c}-43.87 \\
{[6.124]^{* *}}\end{array}$ & $\begin{array}{c}-126.551 \\
{[11.174]^{* *}}\end{array}$ & $\begin{array}{c}515.157 \\
{[441.018]}\end{array}$ & $\begin{array}{c}600.45 \\
{[852.858]}\end{array}$ \\
\hline Traditional User x TFT x Imports2 & & $\begin{array}{c}66.349 \\
{[47.814]}\end{array}$ & & $\begin{array}{c}71,705.43 \\
{[206,287.278]}\end{array}$ \\
\hline Traditional User x Club Effect x Imports2 & & $\begin{array}{c}1,504.10 \\
{[112.670]^{* *}}\end{array}$ & & $\begin{array}{c}-69,209.65 \\
{[206,253.146]}\end{array}$ \\
\hline Traditional User x Imports & $\begin{array}{c}64.928 \\
{[3.656]^{* *}}\end{array}$ & $\begin{array}{c}166.598 \\
{[7.711]^{* *}}\end{array}$ & $\begin{array}{c}120.615 \\
{[14.718]^{* *}}\end{array}$ & $\begin{array}{c}293.154 \\
{[32.954]^{* *}}\end{array}$ \\
\hline Traditional User x Imports2 & & $\begin{array}{c}-1,633.29 \\
{[105.370]^{* *}}\end{array}$ & & $\begin{array}{c}-5,549.37 \\
{[921.847]^{* *}}\end{array}$ \\
\hline Traditional User x \%Delta Imports & $\begin{array}{c}-0.061 \\
{[0.025]^{*}}\end{array}$ & $\begin{array}{c}-0.064 \\
{[0.027]^{*}}\end{array}$ & $\begin{array}{c}-0.085 \\
{[0.059]}\end{array}$ & $\begin{array}{c}0.696 \\
{[0.230]^{* *}}\end{array}$ \\
\hline Traditional User x \%Delta Imports2 & & $\begin{array}{c}0 \\
{[0.000]^{*}}\end{array}$ & & $\begin{array}{c}-0.969 \\
{[0.294]^{* *}}\end{array}$ \\
\hline New User $\mathrm{x}$ TFT & $\begin{array}{c}-0.113 \\
{[0.094]}\end{array}$ & $\begin{array}{c}-0.209 \\
{[0.102]^{*}}\end{array}$ & $\begin{array}{c}-0.332 \\
{[0.143]^{*}}\end{array}$ & $\begin{array}{c}-0.611 \\
{[0.173]^{* *}}\end{array}$ \\
\hline New User x Club Effect & $\begin{array}{c}1.154 \\
{[0.078]^{* *}}\end{array}$ & $\begin{array}{c}1.172 \\
{[0.082]^{* *}}\end{array}$ & $\begin{array}{c}1.514 \\
{[0.113]^{* *}}\end{array}$ & $\begin{array}{c}1.526 \\
{[0.124]^{* *}}\end{array}$ \\
\hline New User x TFT x Imports & $\begin{array}{c}-35.552 \\
{[12.791]^{* *}}\end{array}$ & $\begin{array}{c}-21.154 \\
{[27.388]}\end{array}$ & $\begin{array}{c}-12.28 \\
{[22.665]}\end{array}$ & $\begin{array}{c}82.456 \\
{[63.964]}\end{array}$ \\
\hline New User x Club Effect x Imports & $\begin{array}{c}11.861 \\
{[17.031]}\end{array}$ & $\begin{array}{c}-152.594 \\
{[53.528]^{* *}}\end{array}$ & $\begin{array}{c}-48.917 \\
{[26.963]}\end{array}$ & $\begin{array}{c}-334.968 \\
{[93.383]^{* *}}\end{array}$ \\
\hline New User x TFT x Imports2 & & $\begin{array}{c}13.03 \\
{[769.768]}\end{array}$ & & $\begin{array}{c}-2,873.52 \\
{[2,534.934]}\end{array}$ \\
\hline New User x Club Effect x Imports2 & & $\begin{array}{c}10,005.76 \\
{[3,687.251]^{* *}}\end{array}$ & & $\begin{array}{c}20,795.18 \\
{[7,283.504]^{* *}}\end{array}$ \\
\hline New User x Imports & $\begin{array}{c}41.592 \\
{[11.747]^{* *}}\end{array}$ & $\begin{array}{c}215.72 \\
{[46.484]^{* *}}\end{array}$ & $\begin{array}{c}84.816 \\
{[17.377]^{* *}}\end{array}$ & $\begin{array}{c}431.932 \\
{[78.343]^{* *}}\end{array}$ \\
\hline New User x Imports2 & & $\begin{array}{c}-10,244.97 \\
{[3,606.287]^{* *}}\end{array}$ & & $\begin{array}{c}-23,079.17 \\
{[7,009.086]^{* *}}\end{array}$ \\
\hline New User x \%Delta Imports & $\begin{array}{l}-0.008 \\
{[0.005]}\end{array}$ & $\begin{array}{c}-0.008 \\
{[0.005]}\end{array}$ & $\begin{array}{c}-0.037 \\
{[0.021]}\end{array}$ & $\begin{array}{c}-0.034 \\
{[0.039]}\end{array}$ \\
\hline New User $\mathrm{x} \%$ Delta Imports2 & & $\begin{array}{c}0 \\
{[0.000]}\end{array}$ & & $\begin{array}{c}0 \\
{[0.002]}\end{array}$ \\
\hline Imports - All Suppliers & $\begin{array}{c}-0.107 \\
{[0.035]^{* *}}\end{array}$ & $\begin{array}{c}-0.622 \\
{[0.082]^{* *}}\end{array}$ & $\begin{array}{c}-1.331 \\
{[0.271]^{* *}}\end{array}$ & $\begin{array}{c}-3.043 \\
{[0.823]^{* *}}\end{array}$ \\
\hline Imports All Suppliers2 & & $\begin{array}{c}0.135 \\
{[0.023]^{* *}}\end{array}$ & & $\begin{array}{c}1.559 \\
{[1.193]}\end{array}$ \\
\hline Constant & $\begin{array}{c}-1.824 \\
{[0.107]^{* *}}\end{array}$ & $\begin{array}{c}-1.849 \\
{[0.114]^{* *}}\end{array}$ & $\begin{array}{c}-1.643 \\
{[0.128]^{* *}}\end{array}$ & $\begin{array}{c}-1.532 \\
{[0.142]^{* *}}\end{array}$ \\
\hline Observations & 20684 & 20684 & 7088 & 7088 \\
\hline
\end{tabular}




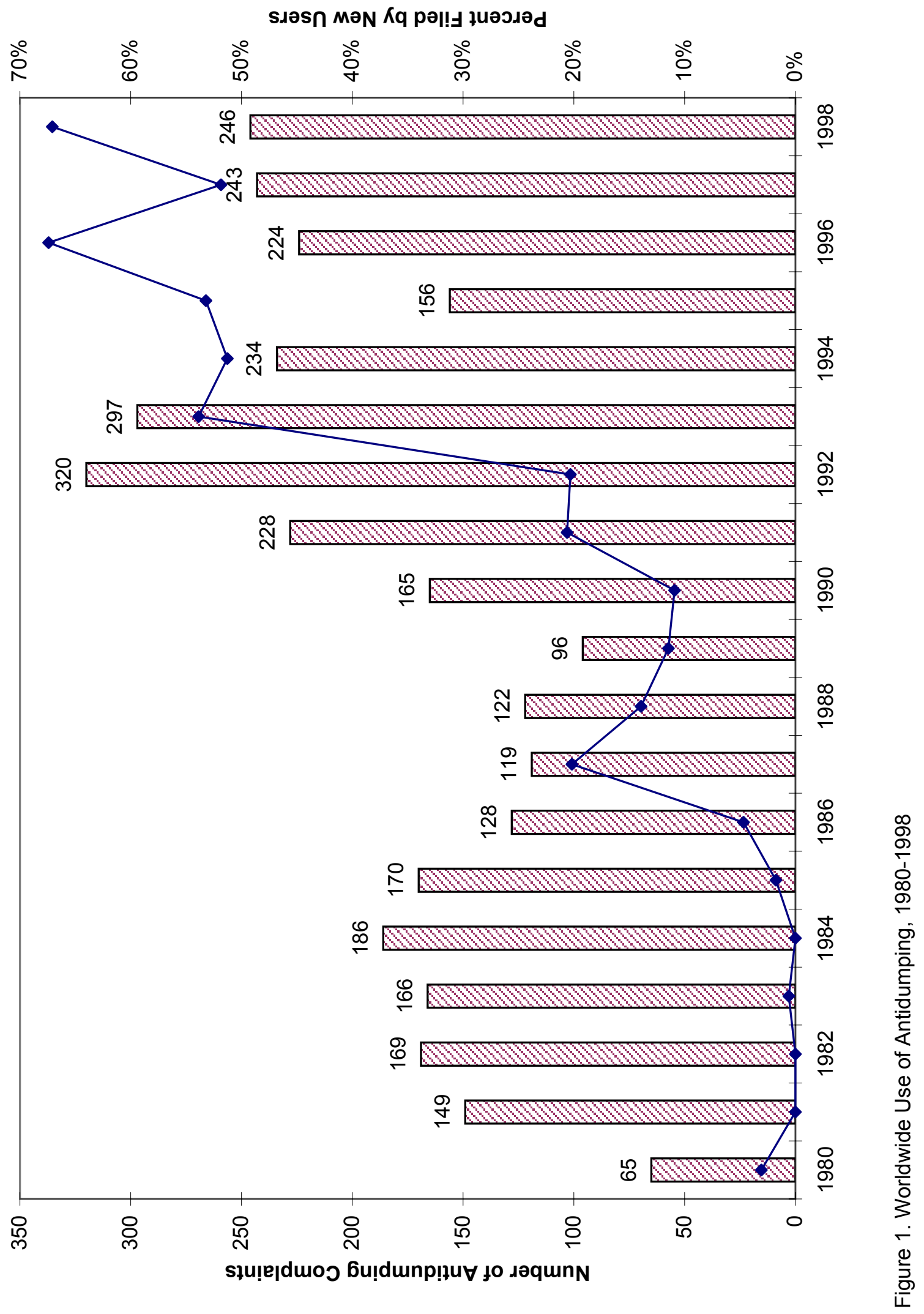




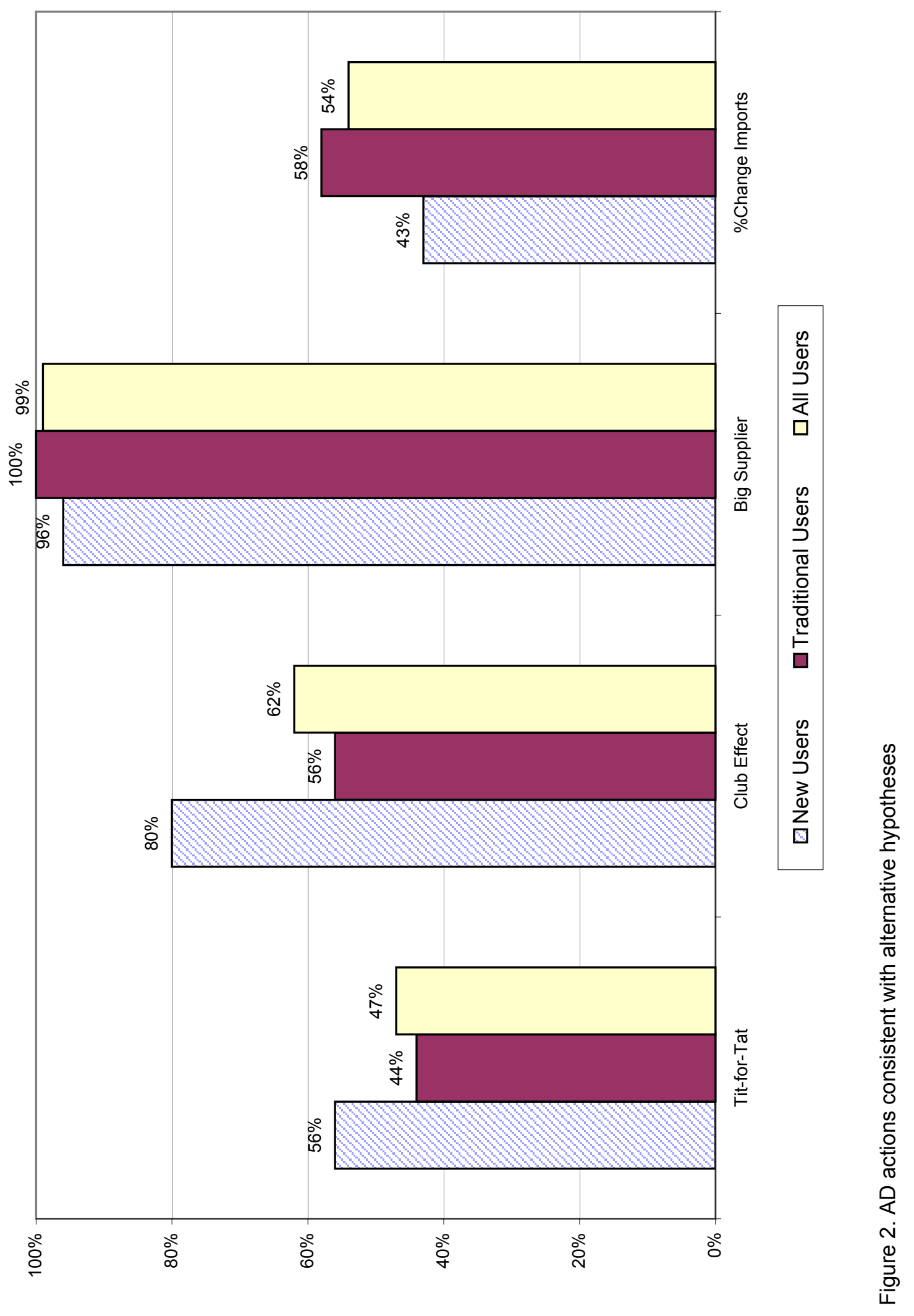




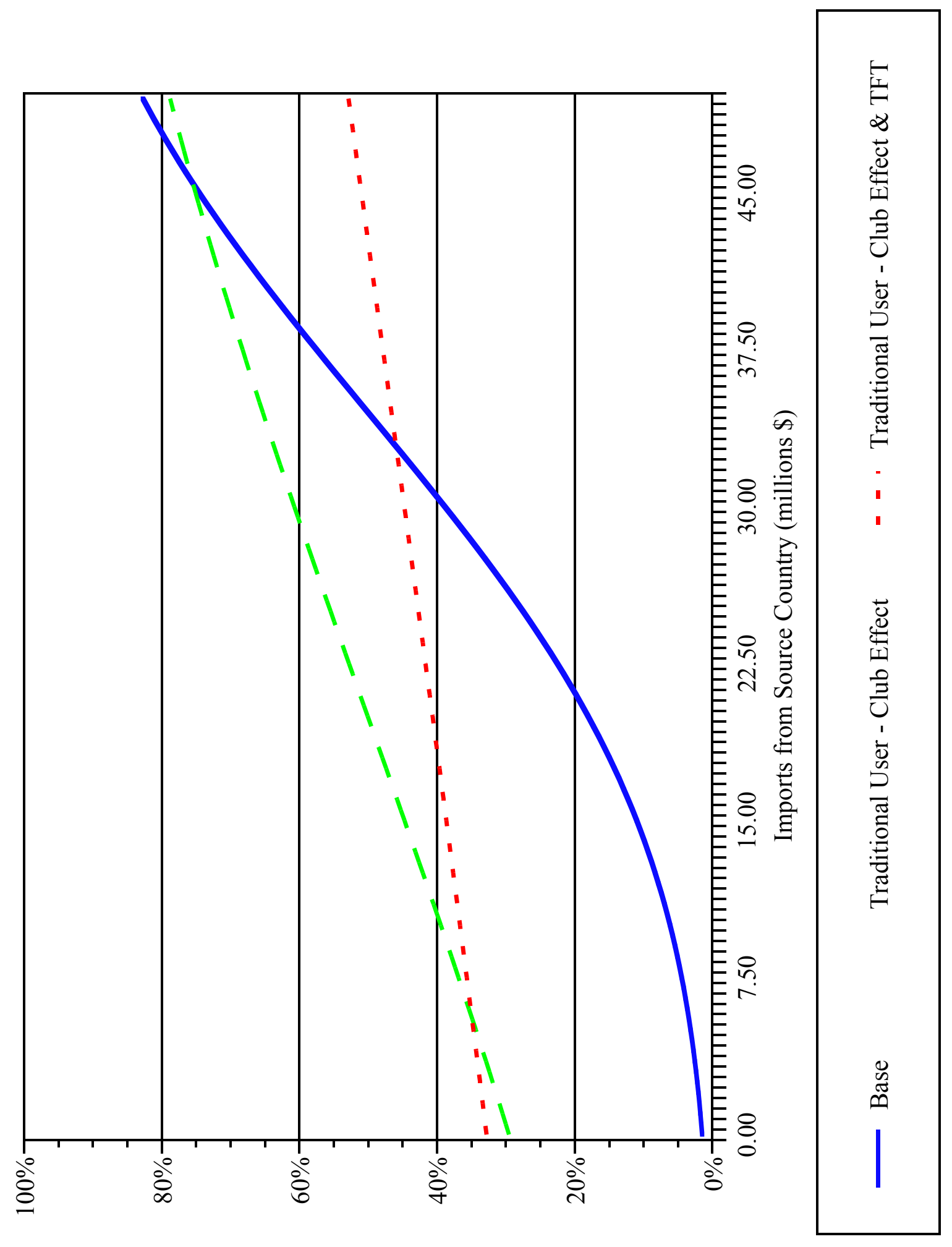

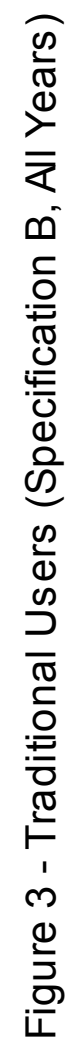




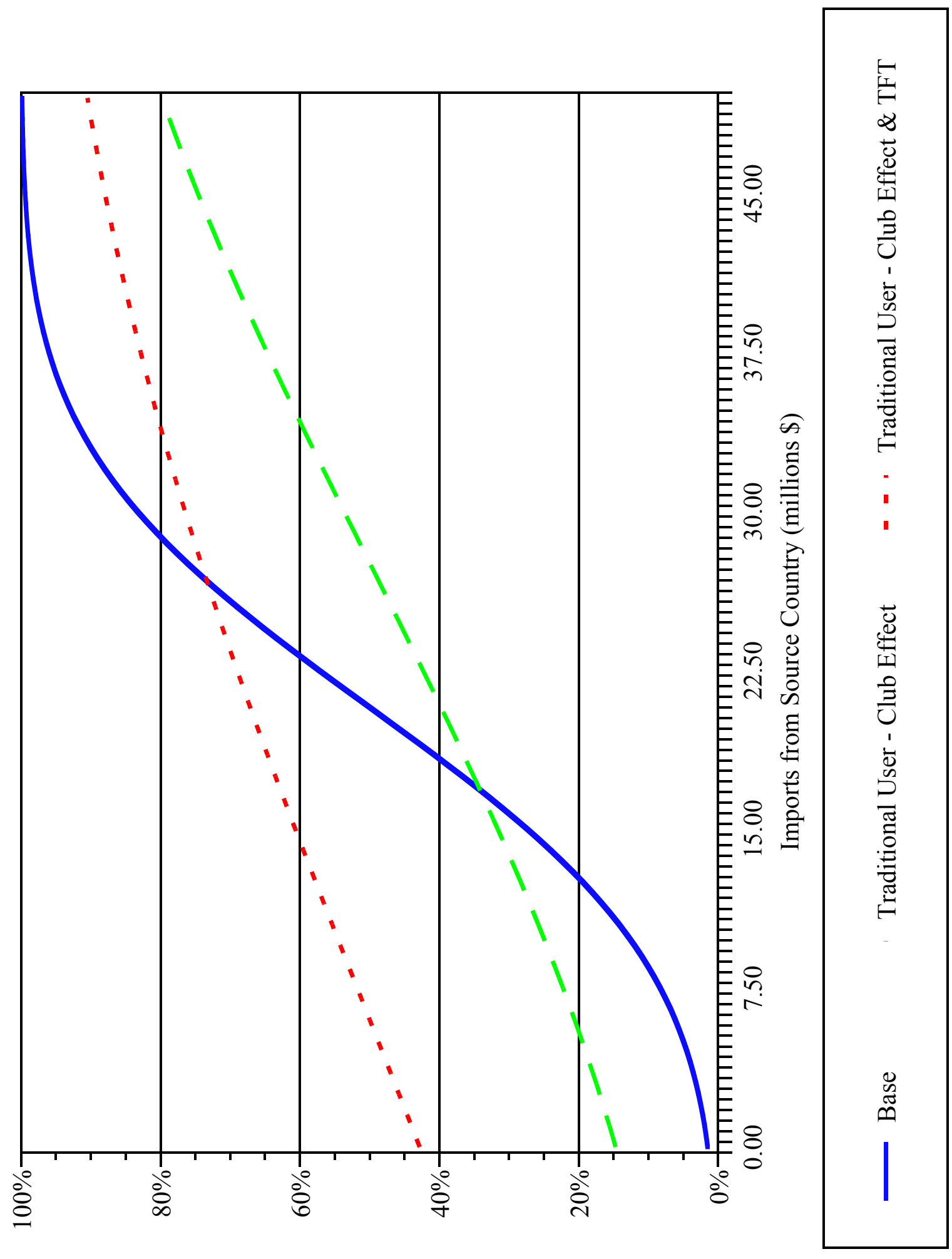

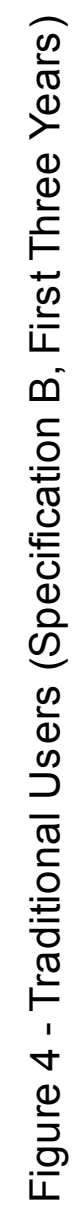




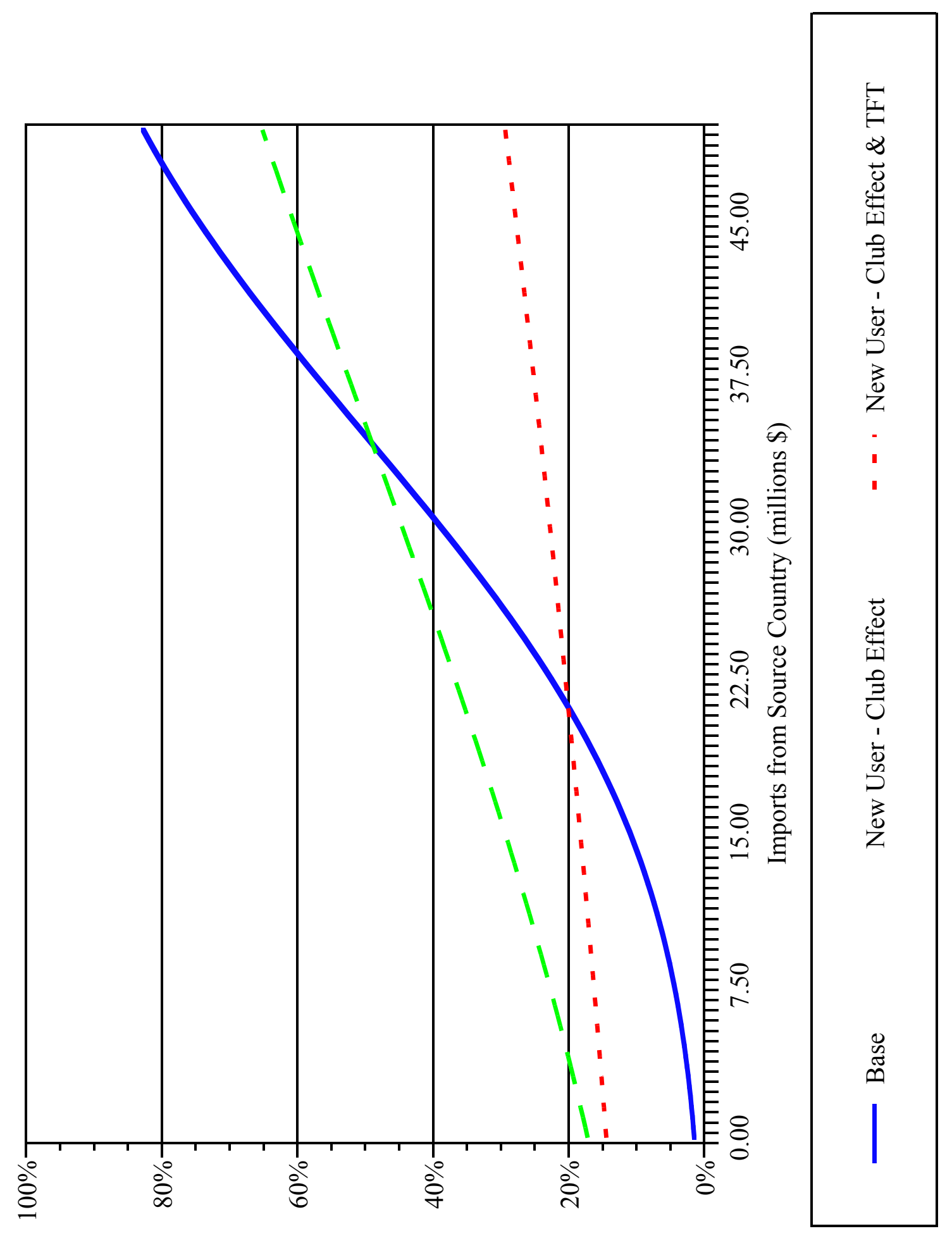

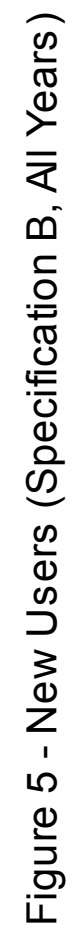



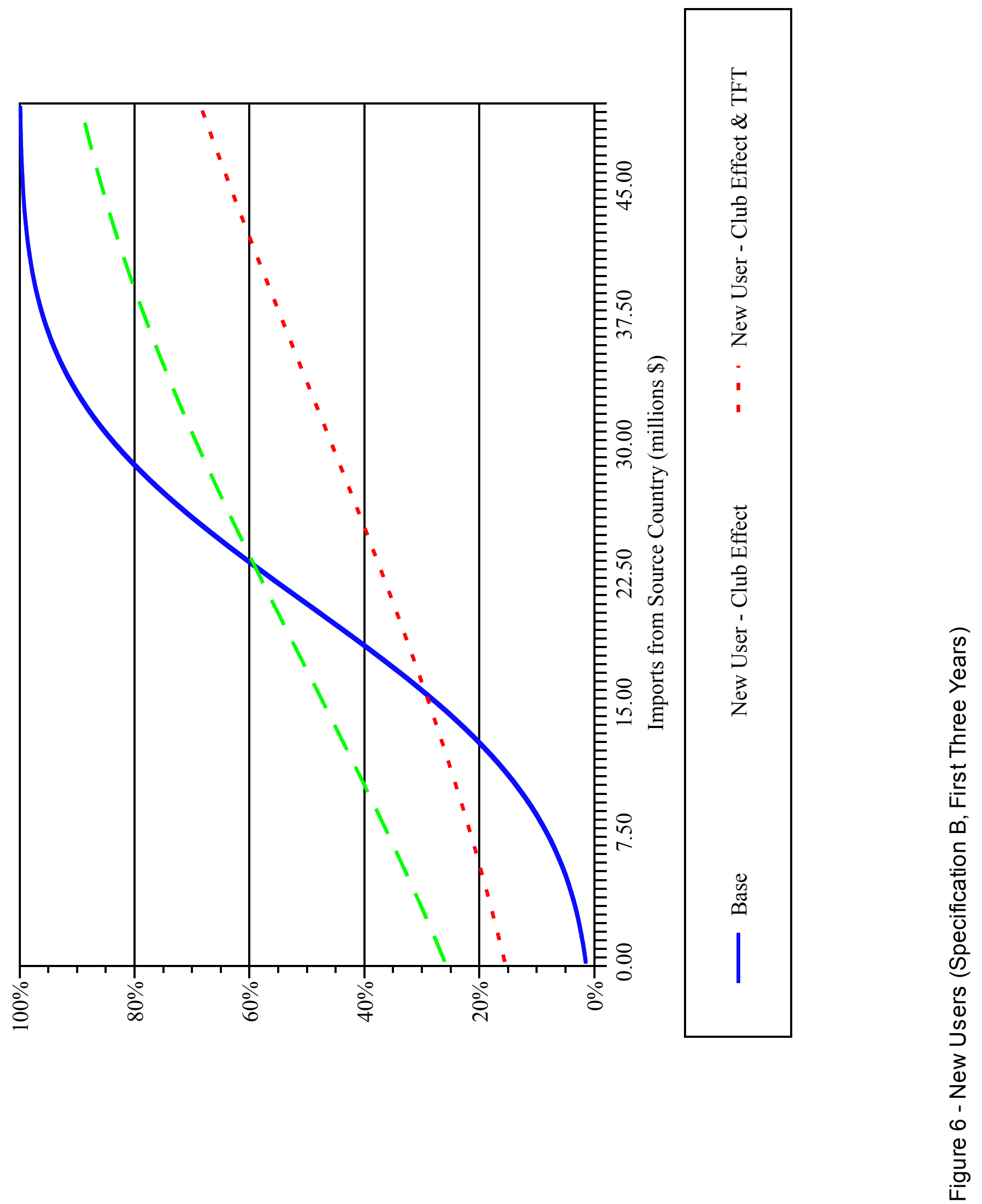